\title{
Formulation and Evaluation of Sintered Floating Tablets of Cefpodoxime Proxetil
}

\section{Sefpodoksim Proksetilin Sinterlenmiş Yüzen Tabletlerinin Formülasyonu ve Değerlendirilmesi}

\author{
(D) Latha KUKATI*, (D) Kishore CHITTIMALLI, (D) Naseeb Basha SHAIK, (D) Shailaja THOUDOJU \\ G. Pulla Reddy College of Pharmacy, Department of Pharmaceutics, Hyderabad, India
}

\begin{abstract}
Objectives: To develop sintered floating tablets of CP using locust bean gum as a release-controlling material. CP is an orally- administered, extended-spectrum, semi-synthetic antibiotic of the cephalosporin class.

Materials and Methods: CP has a short elimination half-life, possesses high solubility, chemical, enzymatic stability and absorption profiles in acidic $\mathrm{pH}$, which makes it a suitable candidate for formulation in a gastro-retentive dose form for improved bioavailability. Camphor was used to get the desired floating properties. The prepared CP floating tablets were subjected to sintering, where the cross linkage within the polymeric structure was increased by exposing the tablets to acetone vapors. The advantage with sintering is that prolonged drug release can be attained at low hardness and low concentrations of polymers.

Results: The prepared tablets were evaluated and found to have acceptable physicochemical properties. Formulation S2 containing locust bean gum: drug (0.3:1.0) and camphor (10\% w/w), which was exposed to acetone vapors for a period of 6 hrs showed optimum floating properties and a better dissolution profile i.e. $97.3 \%$ in 12 hrs. Hence, formulation S2 was considered as the optimized formulation. The in vitro release data of the optimized formulation was treated with mathematical equations and the drug release followed zero-order kinetics (0.9599) with an anomalous transport mechanism (0.5331).

Conclusion: Based on the results, it can be concluded that sintered floating matrix tablets of CP containing locust bean provides a better choice for controlled release.
\end{abstract}

Key words: Cefpodoxime proxetil, controlled material, gastro-retentive floating tablets, sintering technique

Öz

Amaç: CP'nin, keçiboynuzu zamkını salım kontrol edici bir materyal olarak kullanımıyla sinterlenmiş yüzen tabletler geliștirmektir. CP, sefalosporin sınıfının oral yolla uygulanan genişletilmiş spektrumlu, yarı sentetik bir antibiyotiğidir.

Gereç ve Yöntemler: CP, kısa bir eliminasyon yarı ömrüne sahiptir, asidik pH'da yüksek çözünürlük, kimyasal, enzimatik stabilite ve absorpsiyon profillerine sahiptir, bu da, biyoyararlanımın iyileștirilmesi için midede kalan dozaj formuna uygun bir aday olmasını sağlar. İstenen yüzme özelliklerini elde etmek için kafur kullanıldı. Hazırlanan CP yüzen tabletler, sinterlemeye tabi tutuldu; burada polimerik yapı içindeki çapraz bağlantı, tabletleri aseton buharlarına maruz bırakarak arttııılı. Sinterlemenin avantajı, uzun süreli etkin madde salımının düșük sertlikte ve düșük konsantrasyonlarda polimerlerle elde edilebilmesidir.

Bulgular: Hazırlanan tabletler değerlendirildi ve kabul edilebilir fizikokimyasal özelliklere sahip olduğu bulundu. Altı saat süre ile aseton buharlarına maruz bırakılan keçiboynuzu zamkı: etkin madde (0.3:1.0) ve kafur (\%10 a/a) içeren formülasyon S2, optimum yüzme özellikleri ve 12 saatte \%97.3 gibi daha iyi bir çözünme profili gösterdi. Bunun sonucu olarak formülasyon S2 optimize edilmiş formülasyon olarak kabul edildi. Optimize edilmiş formülasyonun in vitro salım verileri, matematiksel denklemlere uygulandı ve etkin madde salımı, anomalous transport mekanizması (0.991) ile sıfır derece kinetiğe (0.9599) uyum gösterdi.

Sonuç: Sonuçlara göre, sefpodoksim proksetilin keçiboynuzu içeren sinterlenmiş yüzen matriks tabletlerinin kontrollü salım için daha iyi bir seçenek sağladığı sonucuna varılabilir.

Anahtar kelimeler: Sefpodoksim proksetil, kontrollü materyal, midede kalan yüzen tabletler, sinterleme tekniği

*Correspondence: E-mail: lathakukatil@gmail.com, Phone: +9848630966 ORCID-ID: orcid.org/0000-0001-7785-2111

Received: 27.07.2017, Accepted: 28.09.2017

๑Turk J Pharm Sci, Published by Galenos Publishing House. 


\section{INTRODUCTION}

Gastro-retentive systems swell and are retained in the stomach for a number of hours, while it continuously releases the drug at a controlled rate leading to higher bioavailability, therapeutic efficacy, reduced time intervals for drug administration, and thus improved patient compliance. Hence these gastro-retentive drug delivery systems (GRDDS) are advantageous for drugs absorbed mainly from the upper part of the gastrointestinal (GI) tract (GIT) because they have a narrow absorption window and are unstable in the medium of distal intestinal regions.' They are even beneficial in the local therapy of the stomach. Compounding drugs with narrow absorption windows in a GRDDS would enable an extended absorption phase of these drugs. ${ }^{2}$ The retention of oral dose forms in the upper GIT causes prolonged contact time of drug with the Gl mucosa.

Sintering techniques: Sintering is defined as "the bonding of adjacent particle surfaces in a mass of powder, or in a compact, by the application of heat or by exposing to solvents". The sintering process has been used for the fabrication of sustained-release (SR) matrix tablets for the stabilization and retardation of the drug release.

Sintering means fusion of particles or formulations of welded bonds between particles of a polymer. In other words, sintering increases the cross-linking between particles in the polymer. Sintering can be achieved by physical (thermal) ${ }^{3}$ and chemical (solvent casting) 4.5 $^{4}$ methods.

Physical method: It includes exposing the dose form to different temperatures, then polymer molecules rearrange at high temperature and result in increased cross- linking in the dose forms.

Thermal sintering: SR oral dose forms are exposed to temperatures above the glass transition point of the polymer, which melts or deforms min amounts of polymer on the surface. These molecules move on the polymer or move into the crosslinked structure of the polymer and become entangled in the three-dimensional structure of the polymer, thereby increasing the complexity, which results in decreased drug release by increased retardation hardness of the dose forms.

Chemical method: This includes exposing the dose form to solvent for different time periods. In this method, polymer molecules undergo partial solubilization in a given solvent and then reoriented to give denser forms with new cross-linking by forming bonds between the polymer molecules. Generally, the cross-linking solvents used are acetone, glutaraldehyde, and formaldehyde.

Solvent casting method: In this method, the prepared tablets are exposed to acetone vapors as a cross-linking agent. CP is available for oral dosing as an ester-prodrug, which keeps it stable and increases the oral absorption and is less likely to produce Gl upset, palatability problems, and changes in intestinal flora prior to absorption. In present study, a CP floating drug delivery system was prepared using locust bean gum as a rate-retarding material. The prepared tablets were subjected to sintering using acetone as a cross-linking agent.

\section{MATERIALS AND EXPERIMENTAL WORK}

\section{Materials}

Cefpodoxime proxetil was received as a gift sample from Micro Labs Pvt. Ltd., Bangalore. Polyvinylpyrrolidone (PVP) K30 was obtained from Burgoyne Burbidges \& Co., Mumbai. Magnesium stearate was purchased from SD fine chemicals, Mumbai. Locust bean gum was purchased from Himedia laboratories Pvt. Ltd., which contains galactomannans (plant reserve carbohydrates present in large quantities in the endosperm of the seeds of many leguminosae such as Ceratonia silique). Chemically, they consist of a (1-4)-linked $\beta$-D-mannose backbone with (1-6)-linked side chains of $\alpha$-D-galactose, ${ }^{6,7}$ thus being neutral polymers. ${ }^{8}$ Citric acid anhydrous was purchased from Universal Laboratories, Mumbai. Camphor was purchased from SigmaAldrich Chemicals Pvt. Ltd., Mumbai, and all other chemicals, reagents, and solvents used were of analytical grade.

\section{Experimental work}

$\mathrm{CP}$ has good stability and solubility in acidic pHs. Tablets were prepared by wet granulation using locust bean gum as a retardant material.

\section{Preformulation studies}

Preformulation studies are performed for testing the physical and chemical properties of a drug substance alone and in combination with excipients.

\section{Precompression parameters of powder blends and granules}

Required quantities of all the ingredients were subjected to grinding then passed through a no. \#60 sieve. The granules were prepared by blending powder with PVP K30 in iso propyl alcohol (IPA) as a granulating agent and the wet mass was screened using a no. \#44 sieve, then dried at $40^{\circ} \mathrm{C}$ in a hot air oven. The powder blend and dried granules were tested for flow properties using the angle of repose, bulk density (BD), tapped density (TD), Carr's index, and Hausner's ratio.'

\section{Angle of repose}

Angle of repose is the angle between the surface pile of granules and a horizontal plane. A fixed amount of blend was taken and carefully poured through the funnel whose tip was fixed at a height of $2.5 \mathrm{~cm}$ above graph paper, which was placed on a horizontal surface. The blend of the powder was poured till the apex of the conical pile just touches the tip of the funnel. The angle of repose is calculated using the following formula.

$\theta=\operatorname{Tan}^{-1}(h / r)$

Where, $\theta=$ angle of repose, $r=$ radius of the pile, $h=$ height of the pile

\section{$B D$}

$B D$ is defined as the ratio mass of an untapped powder divided by the bulk volume (V) including the inter-particulate void spaces. Apparent BD was determined by pouring the blend into a graduated cylinder. The bulk $V$ and weight of the powder (M) was determined. The BD was calculated using the following formula:

$\mathrm{BD}=\mathrm{M} / \mathrm{V}$ 
$T D$

A measuring cylinder containing a known mass of blend was tapped for a fixed time (around 100 taps). The minimum volume $\left(V_{t}\right)$ ccupied in the cylinder and the weight $(M)$ of the blend was measured. The TD was calculated using the following formula:

$\mathrm{TD}=\mathrm{M} /\left(\mathrm{V}_{\mathrm{t}}\right)$

\section{Carr's index}

The compressibility index is an indirect measure of $\mathrm{BD}$, size, shape, surface area, moisture content, and cohesiveness of powder. The correlation between compressibility index and powder flow properties is given in the following formula:

$\mathrm{Cl}(\%)=\mathrm{TD}-\mathrm{BD} / \mathrm{TD} \times 100$

Hausner's ratio

This is an indirect index of ease of powder flow and is measured by the ratio of TD to $B D$.

Hausner's ratio $=T D / B D$

\section{Drug-excipient compatibility studies}

\section{Fourier-trasform infrared (FTIR)}

The spectrum analysis of pure drug and physical mixture of drug and different excipients used for the preparation of tablets was studied using FTIR. FTIR spectra were recorded by preparing potassium bromide $(\mathrm{KBr})$ discs using a Shimadzu Corporation (Koyto, Japan). $\mathrm{KBr}$ discs were prepared by mixing a few milligrams of sample with $\mathrm{KBr}$ and compressed at 10 tons pressure. The resultant disc was mounted in a suitable holder in an IR spectrophotometer and the spectrum was recorded from $4000 \mathrm{~cm}^{-1}$ to $500 \mathrm{~cm}^{-1}$. The resultant spectrum was compared for any spectral changes. They were observed for the presence of characteristic peaks for the respective functional group in the compound.

\section{Formulation of cefpodoxime proxetil floating tablets}

\section{Dose calculation}

Cefpodoxime is available in proxetil salt form. Dose is calculated based on its $t_{1 / 2}$ and $V d$.

$\mathrm{K}^{0} \mathrm{r}=$ Rate in = Rate out $=\mathrm{Ke} \times \mathrm{Cd} \times \mathrm{V}$

Where $\mathrm{K}^{0} \mathrm{r}$ is the zero-order rate constant for drug release (amount/time), $\mathrm{Ke}$ is the first-order rate constant of overall drug elimination $\left(\mathrm{hr}^{-1}\right), \mathrm{Cd}$ is the desired drug level in the body (amount/V), and $\mathrm{Vd}$ is the $\mathrm{V}$ in which the drug is distributed.

$K_{e}=0.693 / t_{1 / 2}$
The $t_{1 / 2}$ (elimination half-life) of CP is 2.4 hours, thus $\mathrm{Ke}=$ $0.693 / 2.4=0.288 \mathrm{hr}^{-1}$

$\mathrm{Cd}$ is $1.4 \mathrm{mg} / \mathrm{L}$, and $\mathrm{Vd}$ is $32.3 \mathrm{~L}$, then $\mathrm{K}^{0} \mathrm{r}=\mathrm{Ke} \times \mathrm{Cd} \times \mathrm{Vd}=0.288$ $\times 1.4 \times 32.3=13.05 \mathrm{mg} / \mathrm{h}$.

$\mathrm{K}^{0} \mathrm{r}$ was calculated as $13.05 \mathrm{mg} / \mathrm{h}$, so the drug release constant should also have been equal to the elimination constant to maintain the steady-state condition.

Cefpodoxime only has $50 \%$ oral absorption in fasting conditions, whereas it is $~ 75 \%$ with food

$\mathrm{K}^{0} \mathrm{r}=13.05 \times 125 / 100=16.32 \mathrm{mg} / \mathrm{h}$

Loading dose $(\mathrm{DL})=\mathrm{Di}-\mathrm{K}^{0} \mathrm{r} \mathrm{Tp}$

Time to reach the peak drug level $(T p)$ is 2.5 hours.

Maintenance dose $(\mathrm{Dm})=\mathrm{K}^{0} \mathrm{r} \mathrm{Td}$

Total dose $=\mathrm{DL}+\mathrm{Dm}$

Where $\mathrm{Td}$ is the total time desired for $\mathrm{SR}$ from 1 dose (i.e., 12 hours).

Hence, total dose $=(100-16.32 \times 2.5)+16.32 \times 12=(100-$ $40.8)+195.28=255.04$

Since $130 \mathrm{mg}$ of cefpodoxime proxetil is equivalent to $100 \mathrm{mg}$ of cefpodoxime.

$=255.04 \times 1.3=331.55 \mathrm{mg}$. Hence the dose used was $330 \mathrm{mg} /$ tablet.

Preparation of tablets by wet granulation using a sublimating agent

The tablets were prepared through wet granulation using sublimating agent. All the ingredients, locust bean gum and drug were passed through a no. \#60 sieve. Granules were prepared using 5\% PVP in IPA as a binder solution and passed through a no. \#44 sieve. Granules were dried at $40^{\circ} \mathrm{C}$ for $2 \mathrm{hrs}$ and passed through a no. \#30 sieve. Camphor was added according to the respective formula and lubricated with magnesium stearate. Formulations were prepared as given in Table 1 and the final blend was compressed into tablets on a 10-station rotary tablet machine using 11.9 punches. The prepared tablets were sublimated in a hot air oven at $60^{\circ} \mathrm{C}$ for 3 days. Tablets with a final weight equal to the theoretical weight after complete sublimation were selected for further experimentation (Figure 1).

\section{Evaluation of cefpodoxime proxetil floating tablets}

The prepared bilayer tablets were evaluated for various parameters such as weight variation, thickness, density, hardness, friability, ${ }^{9}$ drug content, content uniformity, and in vitro dissolution studies. ${ }^{10-12}$

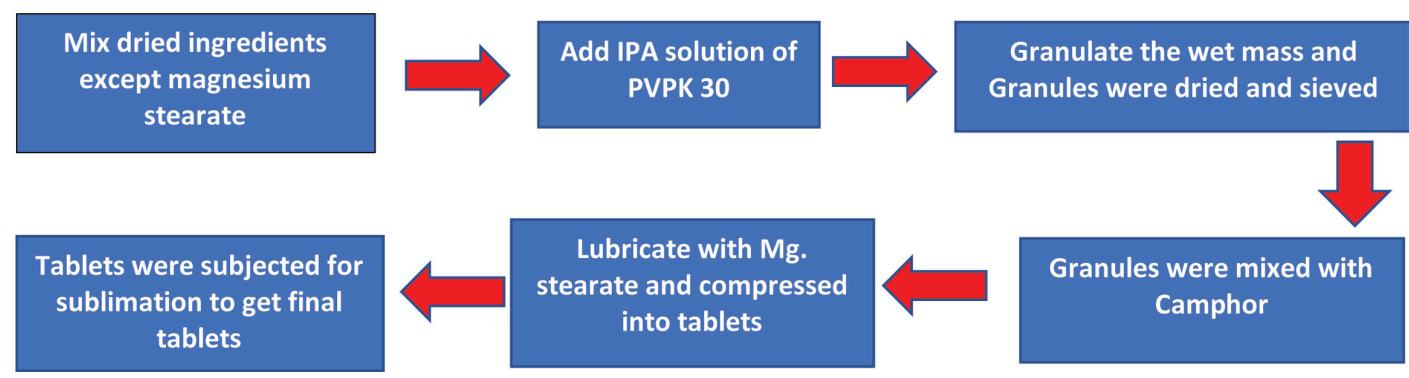

Figure 1. Preparation of cefpodoxime proxetil floating tablets by wet granulation using sublimating agent 


\section{Tablet thickness}

The thickness in millimeters $(\mathrm{mm})$ was measured individually for 10 pre-weighed tablets by Vernier calipers. The average thickness and standard deviation were reported.

\section{Density of tablets}

The density of the sublimated tablets $\left(\mathrm{g} / \mathrm{cm}^{3}\right)$ was calculated both before and after sublimation from the tablet height, diameter, and mass using the following equation:

$\mathrm{D}=\mathrm{W} /\left[(\mathrm{M} / 2)^{2} \times \Pi \times \mathrm{h}\right]$

Where $\mathrm{W}$ is the mass of a tablet, $\mathrm{M}$ is the tablet diameter, $\Pi$ is the circular constant, and $\mathrm{h}$ is the tablet height.

\section{Tablet hardness}

Tablet hardness was measured using a Monsanto hardness tester. The average crushing strength of the 5 tablets with known weight and thickness of each was reported.

\section{Friability test}

Ten tablets were accurately weighed and placed in the friability test apparatus (Roche friabilator), and rotated at $25 \mathrm{rpm}$ for 4 mins. The tablets were taken, dedusted, and reweighed. The friability was calculated as the percentage weight loss using equation 12 . Friability values below $1 \%$ are generally acceptable.

$\%$ Friability $=\left(W_{1}-W_{2}\right) \times 100 / W_{1}$

Where, $W_{1}=$ Initial weight of the tablets, $W_{2}=$ Final weight of the tablets.

\section{Weight variation test}

To study weight variation, individual weights $\left(W_{1}\right)$ of 20 tablets from each formulation were noted using an electronic balance. Their average weight $\left(W_{A}\right)$ and percentage weight variation was calculated using equation 13.

$\%$ Weight variation $=\left(\mathrm{W}_{\mathrm{A}}-\mathrm{W}_{\mathrm{P}}\right) \times 100 / \mathrm{W}_{\mathrm{A}}$

\section{Drug content}

Ten tablets were weighed and taken into a mortar and crushed into a fine powder. An accurately weighed portion of the powder equivalent to $100 \mathrm{mg}$ of $\mathrm{CP}$ was transferred to a $100-\mathrm{mL}$ volumetric flask containing methanol. It was shaken mechanically for $1 \mathrm{hr}$, then filtered using Whatman filter paper. ${ }^{10}$ From this filtrate, $1 \mathrm{~mL}$ was taken, diluted to $10 \mathrm{~mL}$ with $0.1 \mathrm{~N}$ $\mathrm{HCl}$, and the absorbance was measured against a blank at $264.2 \mathrm{~nm}$ using an ultraviolet (UV)-spectrophotometer. The drug content of the floating tablets meets the requirements if the tablet amount lies within the range of $90 \%$ to $110 \%$.

\section{Buoyancy/floating test}

Tablets were placed into a $100-\mathrm{mL}$ beaker containing $0.1 \mathrm{~N} \mathrm{HCl}$ and the time between the introduction and the tablet emerging on the surface of the medium is called the "floating lag time". The total duration of time during which the dose form remains buoyant is called the "total floating time (TFT)".

\section{In vitro dissolution studies ${ }^{10,12}$}

The tablet was placed in a dissolution test apparatus USP II, containing $900 \mathrm{~mL}$ of $0.1 \mathrm{~N} \mathrm{HCl}$ at a speed of $50 \mathrm{rpm}$. A $5 \mathrm{~mL}$ aliquot was withdrawn every $1 \mathrm{hr}$ up to $12 \mathrm{hrs}$ and replaced with $5 \mathrm{~mL}$ of fresh dissolution medium. Each sample was analyzed at $264.2 \mathrm{~nm}$ using a double-beam UV spectrophotometer against a reagent blank.

\section{Sintering}

According to the compositions given in Table 1, tablets were prepared and subjected to sublimation, then these tablets were subjected to lower as well as higher polymeric concentrations prepared using low hardness and subjected to sintering process.

Procedure: The lower chamber of the dessicator was filled with acetone, closed, and kept aside for saturation. After saturation of the chamber, the compressed tablets were placed over a wire-mesh, which is kept above the lower chamber of the dessicator containing acetone. The dessicator is made airtight by closing the lid with the help of vacuum grease. Tablets of each formulation described in Table 2 were exposed to different durations of sintering (1.5, 3.0, 4.5, 6, 7.5, 9 and 10.5 hrs). Finally, the tablets were dried in an oven at $36^{\circ} \mathrm{C}$ for 24 hours and then stored in a vacuum desiccator fused with calcium chloride until further use.

\section{Evaluation of sintered tablets}

Sintered tablets were subjected to various evaluation tests including hardness, friability, buoyancy studies and in vitro dissolution studies. Buoyancy and dissolution studies were performed in $0.1 \mathrm{~N} \mathrm{HCl}$.

\section{Kinetic analysis of dissolution data (model dependent method)}

The dissolution profiles of optimized formula in $0.1 \mathrm{~N} \mathrm{HCl}$ were fitted to zero-order, first-order, Higuchi and Korsemeyer-

Table 1. Formulation of floating tablets

\begin{tabular}{|c|c|c|c|c|c|}
\hline Formulation code & Cefpodoxime proxetil (mg) & Locust bean gum (mg) & Camphor (mg) & Magnesium stearate (mg) & PVP (mg) \\
\hline F1 & 330 & 115.5 & 22.27 & 5 & 23.6 \\
\hline F2 & 330 & 115.5 & 44.55 & 5 & 24.7 \\
\hline F3 & 330 & 115.5 & 66.82 & 5 & 25.8 \\
\hline F4 & 330 & 100 & 21.5 & 5 & 22.8 \\
\hline F5 & 330 & 100 & 43 & 5 & 25.6 \\
\hline F6 & 330 & 100 & 64.5 & 5 & 26.8 \\
\hline
\end{tabular}

PVP: Polyvinylpyrrolidone 
Peppas kinetic models. The model with the highest correlation coefficient was considered to be the best fitting one. By these studies the release mechanisms were determined.

Determination of surface morphology of prepared tablets using scanning electron microscopy (SEM)

The effect of the sublimation material (camphor) on the morphology of the prepared tablets was examined using SEM. The main objective of the study was to examine the surface of the prepared tablets during sublimation before and after sintering.

\section{FTIR studies of sintered matrix tablets}

FTIR studies were performed for the powdered tablets after sintering. The spectrum obtained was observed for the presence of characteristic peaks and compared with pure drug.

Determination of residual acetone using gas chromatography (GC)

\section{Analytical instrument settings}

GC was employed for the determination of acetone in the tablet. The GC used was an Aligent, Model 7890, GC equipped with a flame ionization detector (FID). The analysis was performed under the following chromatographic conditions: Column WCOT Fused Silica, $30 \times 0.32 \times 1.8 \mu \mathrm{m}$. The temperature of the FID was $220^{\circ} \mathrm{C}$, and the injector temperature was $220^{\circ} \mathrm{C}$. The oven temperature was programmed to $40^{\circ} \mathrm{C}$ (for $2 \mathrm{~min}$ ), followed by an increase of $5^{\circ} \mathrm{C} / \mathrm{min}$ until $200^{\circ} \mathrm{C}$. The carrier gas was nitrogen with a flow of $1.5 \mathrm{~mL} / \mathrm{min}$. The injection of test and standard was performed using a 10- $\mu \mathrm{L}$ Hamilton syringe.

Optimized sintered tablets were crushed and taken to 1000$\mathrm{mL}$ volumetric flask and the $\mathrm{V}$ was made up with deionized water. The flask was shaken and kept aside to obtain a clear supernatant. A fixed $V$ of supernatant $(0.5 \mu \mathrm{L})$ was injected into the chromatographic system and the amount of acetone in the tablets was calculated.

Determination of gastric retention period using $X$-ray imaging studies

Evaluation of gastric retention of CP sintered floating tablets was performed on rabbits using a radio opaque marker, barium sulfate. X-ray imaging studies are non-invasive method that provides identification or monitoring of total $G$ l residence time without affecting normal gastrointestinal motility.
Dose translation was based on body surface area (BSA). The animal dose should not be extrapolated to a human equivalent dose (HED) based on body weight by simple conversion. The use of BSA normalization is suggested for more appropriate conversion of doses from humans to animals or vice versa. BSA correlates well with most mammalian species by several parameters of biology, including oxygen use, caloric expenditure, basal metabolism, blood $V$, circulating plasma proteins, and renal function.

The rabbit dose was calculated according to the following equation:

Animal dose $(\mathrm{mg} / \mathrm{kg})=\mathrm{HED} \times$ human $\mathrm{Km}$ value/animal $\mathrm{Km}$ value (14)

To convert dose in $\mathrm{mg} / \mathrm{kg}=$ Dose in $\mathrm{mg} / \mathrm{m}^{2} \times \mathrm{Km}$ value.

Human (human adult of weight $60 \mathrm{~kg}$ ) $\mathrm{Km}$ value 37, animal (rabbit weighing $1.8 \mathrm{~kg}$ ) $\mathrm{Km}$ value 12 .

Values based on data from the United Sates Food and Drug Administration draft guidelines.

Animal dose $(\mathrm{mg} / \mathrm{kg})=5.5 \times 37 / 12=5.5 \times 3.08=16.94 \mathrm{mg} / \mathrm{kg}$.

Rabbit under study weighed $1.9 \mathrm{~kg}$. So, $16.94 \times 1.9=32.1 \mathrm{mg}$.

Hence the dose for in vivo studies taken was $32.1 \mathrm{mg} .25 \%$ of drug was replaced with barium sulfate i.e., so $8.025 \mathrm{mg}$ per each tablet. The formulas for in vivo gastro retentive (GR) tablets are given in Table 3.

The tablets were prepared on 10-station rotary tablet machine using $4 \mathrm{~mm}$ punches. Prepared tablets were sublimated at $60^{\circ} \mathrm{C}$ in a hot air oven for 3 days. The sublimated tablet was exposed to acetone for 6 hours for sintering. The tablets were then dried in the hot air oven at $36^{\circ} \mathrm{C}$ for 24 hours and then stored in vacuum desiccators.

\begin{tabular}{lll}
\multicolumn{3}{l}{ Table 3. Formula according to animal dose } \\
S. No & Ingredient & Quantity taken $(\mathrm{mg})$ \\
\hline 1 & Cefpodoxime proxetil & 24 \\
\hline 2 & Barium sulfate & 8 \\
\hline 3 & Locust bean gum & 7.2 \\
\hline 4 & Camphor & 4 \\
\hline 5 & Magnesium stearate & 0.5 \\
\hline 6 & PVP K30 & 2.18 \\
\hline
\end{tabular}

PVP: Polyvinylpyrrolidone

Table 2. Formulation of sintered tablets containing camphor

\begin{tabular}{llllll} 
Formulation code & Cefpodoxime proxetil $(\mathrm{mg})$ & Locust bean gum $(\mathrm{mg})$ & Camphor $(\mathrm{mg})$ & Magnesium stearate $(\mathrm{mg})$ & PVP $(\mathrm{mg})$ \\
\hline S1 & 330 & 82.5 & 41.2 & 5 & 22.9 \\
\hline S2 & 330 & 100 & 43 & 5 & 23.9 \\
\hline S3 & 330 & 115.5 & 44.5 & 5 & 24.75 \\
\hline S4 & 330 & 132 & 46.2 & 5 & 25.6 \\
\hline
\end{tabular}

PVP: Polyvinylpyrrolidone 
Healthy rabbits of $2.0 \pm 0.2 \mathrm{~kg}$ were fasted over night and in the following morning, tablet formulation S2, which was adjusted to a rabbit dose with tracing radio opaque agent, was administered through plastic tubing followed by flushing of 25$30 \mathrm{~mL}$ of water. During the entire study, the rabbits had free access to water alone. At different time intervals of $0,1,2,4,6$ and 8 hours, the rabbit Gl tract was photographed using X-rays in the supine position and observed for the nature and position of the CP floating tablet.

Determination of stability of tablets after sublimation using thin-layer chromatography (TLC)

The stability of $\mathrm{CP}$, which can be determined by exposure to acetone vapors in a desiccator for 9 hours, was evaluated using TLC.

\section{Procedure}

Preparation of standard solution: An accurately weighed quantity of $10 \mathrm{mg}$ of CP was transferred to a $10-\mathrm{mL}$ volumetric flask an dissolved in methanol. The $V$ was made up with the same solvent to obtain a concentration of $1 \mathrm{mg} / \mathrm{mL}$.

\section{Mobile phase}

Water: Methanol 50:50 v/v composition.

\section{Antimicrobial studies for sintered GR tablets}

The microbial assay is based on a comparison of the inhibition of growth of bacteria by measured concentrations of the compound to be examined with that produced by known concentrations of standard preparation of the antibiotic with known activity.

The microbial assay may be conducted by two methods. Method A: Cylinder or cup-plate diffusion and Method B: Turbidimetric or tube assay.

In the present investigation, the cylinder or cup-plate technique was employed.

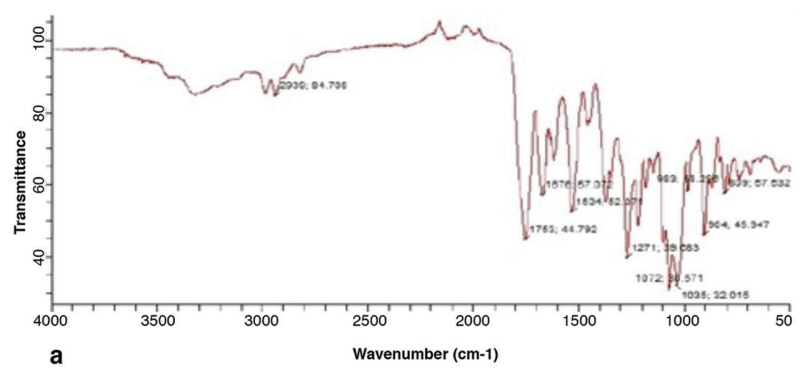

The following strains of bacteria were used for the study.

1. Gram-positive bacteria - Bacillus subtilus

2. Gram-negative bacteria - Escherichia coli

Preparation of standard antibiotic solution

The stock solution ( $1 \mathrm{mg} / \mathrm{mL}$ ) of antibiotics was prepared by dissolving $10 \mathrm{mg}$ of $\mathrm{CP}$ in a volumetric flask containing 10 $\mathrm{mL}$ dimethyl sulfoxide (DMSO). From stock solution, $2 \mathrm{~mL}$ was taken and further diluted to $10 \mathrm{~mL}$ with DMSO to get $10 \mathrm{mg} / 50 \mathrm{~mL}$.

Preparation of test solutions: The formulation was crushed into powder. Powder weight equivalent to $10 \mathrm{mg}$ of drug was dissolved in $10 \mathrm{~mL}$ of DMSO (the drug assay was performed for tablets and equivalent to10 $\mathrm{mg}$ was taken). From this solution, further dilutions were made using DMSO to obtain concentrations of $10 \mu \mathrm{g} / 50 \mu \mathrm{L}, 5 \mu \mathrm{g} / 50 \mu \mathrm{L}, 2.5 \mu \mathrm{g} / 50 \mu \mathrm{L}$, and $1.25 \mu \mathrm{g} / 50 \mu \mathrm{L}$.

\section{Accelerated stability studies}

Optimized formulation F2 was subjected to stability studies at $40^{\circ} \mathrm{C} \pm 2^{\circ} \mathrm{C} / 75 \% \pm 5 \% \mathrm{RH}$ and room temperature, and analyzed for its physical characteristics, drug content, and dissolution studies for a period of one month.

This study was approved by the IAEC (ID No: GPRCP / IAEC / 3 / PCE / AE - 3).

\section{RESULTS AND DISCUSSION}

\section{Preformulation studies}

Drug-excipients compatibility study by FTIR

CP compatibility with excipient was studied using FTIR (Figure 2, Table 4). FTIR results showed that the characteristic functional groups matched those reported in the literature. ${ }^{13}$
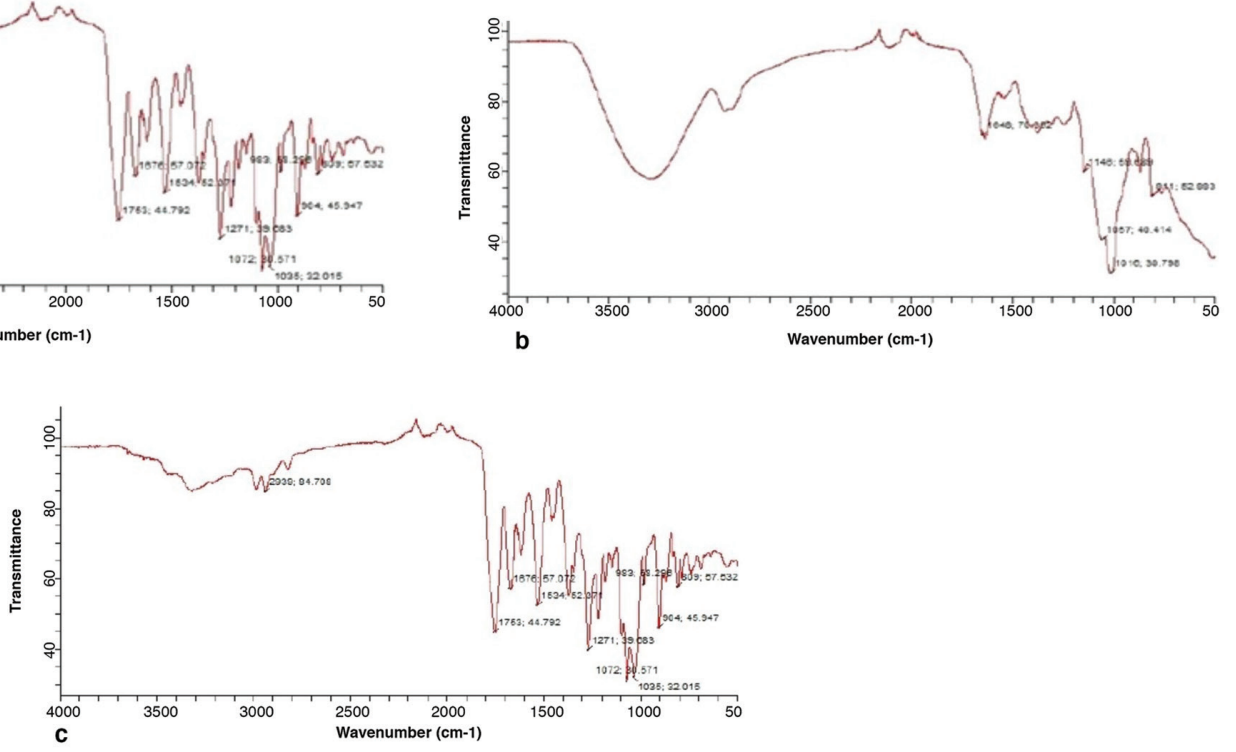

Figure 2. FTIR spectra of (a) cefpodoxime proxetil (b) locust bean gum and (c) physical mixture of cefpodoxime and locust bean gum 
It was found that the drug and the other powder blends do not possess the required flow characteristics for direct compression because the angle of repose, Hausner's ratio, and Carr's compressibility index were not within flow property limits as shown in Table 5 . Hence, tablets were prepared using the wet granulation method.

The flow property values of the granules of all formulations were found to possess good flow properties and were within the compendial limits of the Indian Pharmacopoeia; ${ }^{8}$ the values are shown in Table 6.

\section{Evaluation of CP floating tablets}

Prepared floating tablets were evaluated for physiochemical properties.

The physicochemical evaluation of tablets such as weight variation test, friability, hardness, and content uniformity of all the formulations were within compendial standards. The values are as shown in Table 7.

\section{Effect of sublimation of camphor on tablet properties}

The floating properties of the GR tablets and effects of sublimation on thickness, density, and crush strength (hardness) are summarized in Table 8 .

The crush strength of the tablets decreased after sublimation. As the camphor content in the tablet increased from 5\% to $15 \%$ w/w, the crush strength of the GR tablet decreased, and the densities of the tablets also decreased..$^{14}$ When more than $40 \mathrm{mg}$ of camphor was added to the GR tablet formulations, the density of the tablets was less than $1.00 \mathrm{~g} / \mathrm{cm}^{3}$. In all formulations, the thickness and porosity of tablets slightly increased after sublimation, which resulted in the tablets having a density less than $1 \mathrm{gm} / \mathrm{cm}^{3}$. Thus, the tablets floated on the dissolution media due to air in the porous tablets without any lag time. ${ }^{15}$

\section{Buoyancy/floating test}

In the sublimation method, camphor was used at different concentrations and floating properties were studied (Table 9).

\section{Table 4. Interpretation of cefpodoxime proxetil FTIR scan}

\begin{tabular}{llll} 
S. No & Region in $\mathrm{cm}^{-1}$ & Type of vibration & Functional group present \\
\hline 1 & $3396.41,3230.54$ & $\mathrm{~N}-\mathrm{H}$ stretching & Primary amine \\
\hline 2 & 1676 & $\mathrm{~N}-\mathrm{H}$ bending & Aromatic primary amine \\
\hline 3 & 1274 & $\mathrm{C}-\mathrm{N}$ & Amine \\
\hline 4 & 3066.61 & Aromatic C-H stretch & Aromatic \\
\hline 5 & 1638 & C=N & -- \\
\hline 7 & 809 & C-S-C stretching & -- \\
\hline
\end{tabular}

FTIR: Fourier-transform infrared

\section{Table 5. Precompression parameters of the powder blends}

\begin{tabular}{llll} 
Ingredients & Angle of repose $(\theta)$ & Hausner's ratio* & Carr's index (\%) \\
\hline Drug & $53.3 \pm 0.54$ & $1.40 \pm 0.09$ & $29.67 \pm 0.2$ \\
\hline Drug + locust bean gum & $44.92 \pm 0.13$ & $1.32 \pm 0.04$ & $22.46 \pm 0.15$ \\
\hline Drug + LG + camphor & $50 \pm 0.49$ & $1.46 \pm 0.02$ & $24.1 \pm 0.17$ \\
\hline
\end{tabular}

Values are expressed as mean $\pm S D$, ${ }^{*} n=3$

Table 6. Precompression parameters of the granules

\begin{tabular}{llllll} 
Formulation code & Angle of repose $(\theta)^{*}$ & Bulk density $\left(\mathrm{g} / \mathrm{cm}^{3}\right)^{*}$ & Tapped density $\left(\mathrm{g} / \mathrm{cm}^{3}\right)^{*}$ & Hausner's ratio* & Carr's index $(\%)^{*}$ \\
\hline F1 & $26.76 \pm 0.76$ & $0.310 \pm 0.013$ & $0.392 \pm 0.01$ & $1.23 \pm 0.09$ & $16.84 \pm 0.14$ \\
\hline F2 & $26.26 \pm 1.0$ & $0.344 \pm 0.01$ & $0.432 \pm 0.013$ & $1.137 \pm 0.011$ & $17.06 \pm 0.84$ \\
\hline F3 & $26.34 \pm 0.82$ & $0.361 \pm 0.01$ & $0.346 \pm 0.012$ & $1.228 \pm 0.010$ & $19.39 \pm 0.78$ \\
\hline F4 & $26.26 \pm 0.69$ & $0.368 \pm 0.01$ & $0.458 \pm 0.016$ & $1.234 \pm 0.00$ & $17.87 \pm 0.82$ \\
\hline F5 & $27.54 \pm 0.81$ & $0.346 \pm 0.01$ & $0.428 \pm 0.00$ & $1.226 \pm 0.04$ & $20.19 \pm 0.34$ \\
\hline F6 & $22.47 \pm 0.84$ & $0.322 \pm 0.00$ & $0.421 \pm 0.00$ & $1.395 \pm 0.06$ & $21.72 \pm 0.52$ \\
\hline
\end{tabular}

Values are expressed as mean $\pm S D$, ${ }^{*} n=3$ 
Camphor, upon sublimation, resulted in a slight increase in thickness and also increased porosity, which finally resulted in the tablets having density less than $1 \mathrm{gm} / \mathrm{cm}^{3}$. Tablets so formed floated on dissolution media without any lag time.

Formulations containing $15 \%$ camphor showed floating properties with no lag time, but cracks developed in the tablets after 9 to 10 hours, as a result chipping was observed on tablet surface. Hence, formulations F2 and F5 were found to have optimum floating properties (Figure 3 ).

The formulations with a lag time of less than 30 mins and TFT of greater 12 hours were selected and subjected to dissolution studies for optimization.
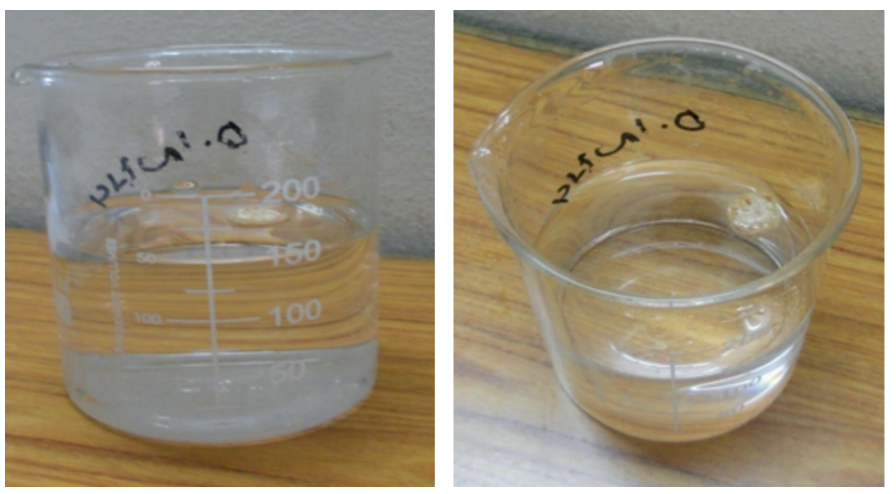

Figure 3. Floating ability (without lag time) of cefpodoxime proxetil tablets containing camphor

\section{In vitro drug dissolution testing of floating tablets}

Based on the floating study results, formulations F2 and F5 were selected and subjected to dissolution studies for further optimization.

Among the different formulations subjected to dissolution studies, formulation F2 (containing a 0.35 ratio of locust bean gum with respect to drug and camphor 10\%) showed a comparatively better dissolution profile of $95.8 \%$ for 12 hours (Figure 4). Based on the results of floating studies (no lag time) and dissolution studies, formulation F2 was selected and subjected to sintering. ${ }^{16}$

\section{Effect of camphor concentration on in vitro release of $C P$}

Different formulations from F1 to F6 were studies with increased amounts of camphor, which led to the decreased density of the resultant GR tablets after sublimation.

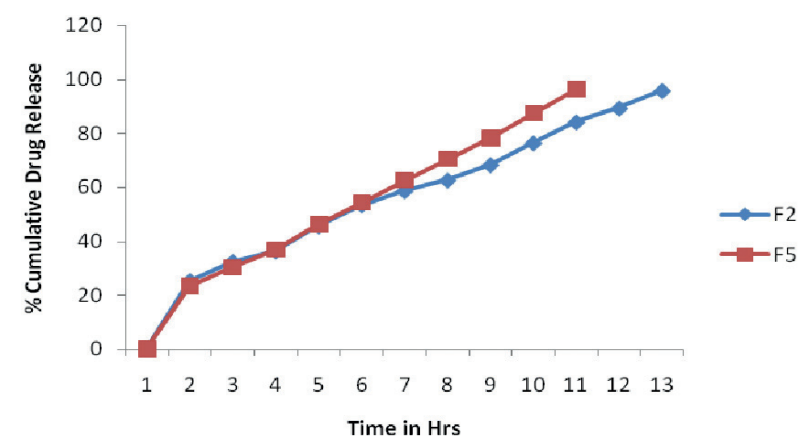

Figure 4. Dissolution profiles of formulations F2 and F5

Table 7. Physiochemical evaluations of tablets containing camphor

\begin{tabular}{llll} 
Formulation code & Drug content (\%) & Weight variation (\%) & Friability $^{\mathrm{a}}$ \\
\hline F1 & $96.4 \pm 0.20$ & $3.03 \pm 0.30$ & $0.62 \pm 0.01$ \\
\hline F2 & $97.1 \pm 0.23$ & $4.02 \pm 0.60$ & $0.55 \pm 0.06$ \\
\hline F3 & $96.8 \pm 0.64$ & $4.1 \pm 0.30$ & $0.71 \pm 0.01$ \\
\hline F4 & $99.4 \pm 0.77$ & $3.9 \pm 0.50$ & $0.77 \pm 0.01$ \\
\hline F5 & $95.3 \pm 0.40$ & $3.7 \pm 0.22$ & $0.71 \pm 0.04$ \\
\hline F6 & $97.6 \pm 0.96$ & $2.8 \pm 0.70$ & $0.69 \pm 0.02$ \\
\hline
\end{tabular}

Values are expressed as mean $\pm S D,{ }^{a}: n=10,{ }^{b}: n=20$

Table 8. Comparison of physical parameters before and after sublimation

\begin{tabular}{lllllll}
\multirow{2}{*}{ Formulation code } & \multicolumn{5}{c}{ Before sublimation } & \multicolumn{5}{c}{ After sublimation } \\
\cline { 2 - 7 } & Thickness $(\mathrm{mm})^{\mathrm{a}}$ & Density $\left(\mathrm{g} / \mathrm{cm}^{3}\right)^{\mathrm{a}}$ & Hardness $\left(\mathrm{kg} / \mathrm{cm}^{2}\right)^{\mathrm{a}}$ & Thickness $(\mathrm{mm})^{\mathrm{a}}$ & Density $\left(\mathrm{g} / \mathrm{cm}^{3}\right)^{\mathrm{a}}$ & Hardness $\left(\mathrm{kg} / \mathrm{cm}^{2}\right)^{\mathrm{a}}$ \\
\hline F1 & $4.6 \pm 0.01$ & $1.10 \pm 0.00$ & $7.1 \pm 0.01$ & $4.8 \pm 0.00$ & $1.02 \pm 0.01$ & $6.2 \pm 0.01$ \\
\hline F2 & $4.8 \pm 0.00$ & $1.03 \pm 0.01$ & $6.9 \pm 0.35$ & $5.1 \pm 0.67$ & $0.873 \pm 0.00$ & $6.1 \pm 0.00$ \\
\hline F3 & $5.0 \pm 0.08$ & $1.08 \pm 0.01$ & $7.3 \pm 0.28$ & $5.3 \pm 0.00$ & $0.84 \pm 0.06$ & $5.8 \pm 0.30$ \\
\hline F4 & $4.5 \pm 0.12$ & $1.12 \pm 0.03$ & $7.1 \pm 0.01$ & $4.7 \pm 0.01$ & $1.01 \pm 0.21$ & $6.0 \pm 0.30$ \\
\hline F5 & $4.7 \pm 0.80$ & $1.03 \pm 0.22$ & $7.0 \pm 0.00$ & $5.1 \pm 0.16$ & $0.84 \pm 0.01$ & $6.1 \pm 0.01$ \\
\hline F6 & $4.9 \pm 0.07$ & $1.05 \pm 0.21$ & $7.2 \pm 0.01$ & $5.3 \pm 0.18$ & $0.82 \pm 0.09$ & $5.7 \pm 0.45$ \\
\hline
\end{tabular}

Values are expressed as mean $\pm S D,{ }^{a}: n=5$ 


\section{Drug release kinetics: Model-dependent method}

The release kinetics for the different formulations was calculated using Microsoft Office Excel, 2007. The release data were analyzed by fitting the drug release profiles of all the formulations into zero-order release, first-order release, Higuchi and Korsmeyer-Peppas models.

From the results of model-dependent kinetic analyses of the dissolution profiles of the formulations $\mathrm{F} 2$ and $\mathrm{F} 5$, it was found that the release of drug from these formulations followed zeroorder kinetics and the mechanism of release was found to be anomalous transport from $r^{2}$ and $n$ values, as shown in Table 10.

\section{Sintering technique}

The prepared floating tablets were exposed to acetone vapors for sintering. Based on the results in the floating test and in vitro dissolution studies, formulation $\mathrm{F} 2$ ( 0.35 ratio polymer to drug) was found to be better when compared with the other formulation. Hence, the 0.35 ratio was selected.

Drug retardation was increased with long exposure times to acetone vapors in formulation S1. This may be due to the crosslinking of polymer as well as the process of sintering. After further exposure to acetone i.e., for 9 hours and 10.5 hours, there was no significant difference in drug release due to saturation of the cross-linking on the tablet surface.

From the dissolution studies of formulations S1 to S3 (Figure 5,6 , and 7 ), it can be concluded that $\mathrm{S} 2$ had better sustained drug release (97.3\%, in 12 hours) on exposure to acetone for 6 hours; therefore, it was selected as the optimized formulation.

\begin{tabular}{lll}
\multicolumn{2}{l}{$\begin{array}{l}\text { Table 9. Floating lag time and floating time of formulation } \\
\text { containing camphor }\end{array}$} \\
\begin{tabular}{lll} 
Formulation code & Floating lag time & Floating time (hrs) \\
\hline F1 & Not floating & - \\
\hline F2 & Floating with no lag time & $>12$ \\
\hline F3 & Floating with no lag time & $\langle 10$ \\
\hline F4 & Not floating & - \\
\hline F5 & Floating with no lag time & $>12$ \\
\hline F6 & Floating with no lag time & $\langle 10$ \\
\hline
\end{tabular}
\end{tabular}

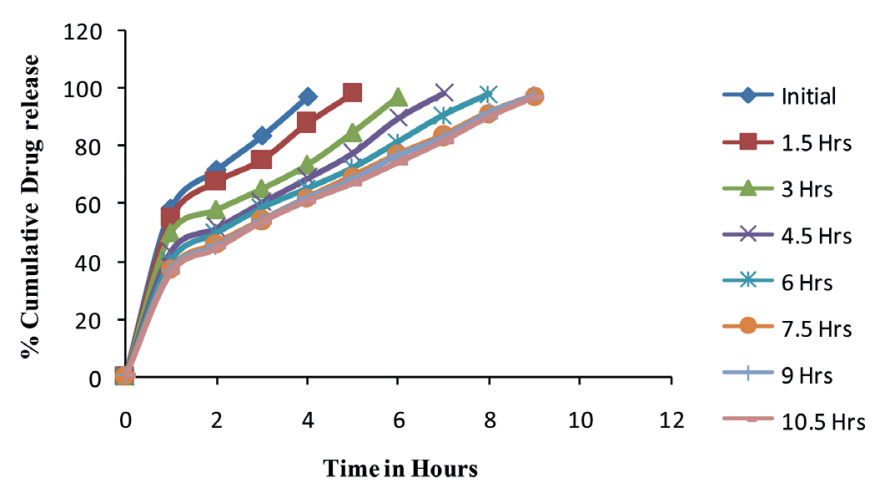

Figure 5. Dissolution profiles of formulation S1

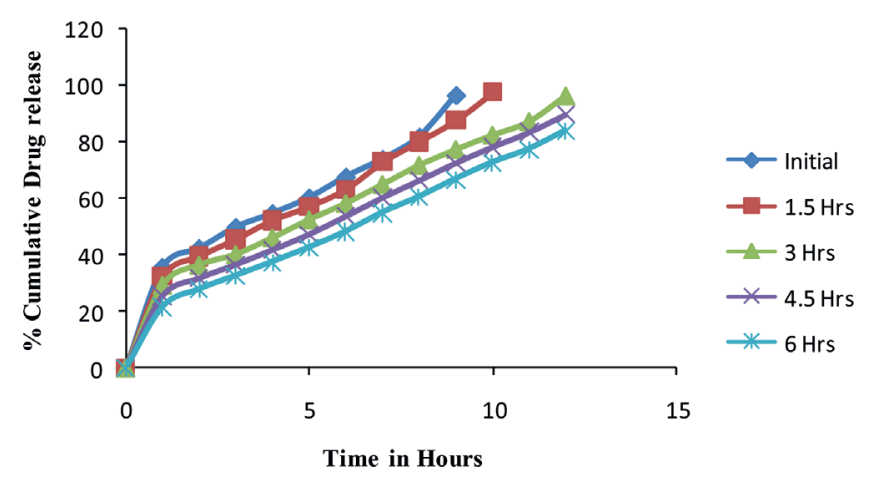

Figure 6. Dissolution profiles of formulation S2

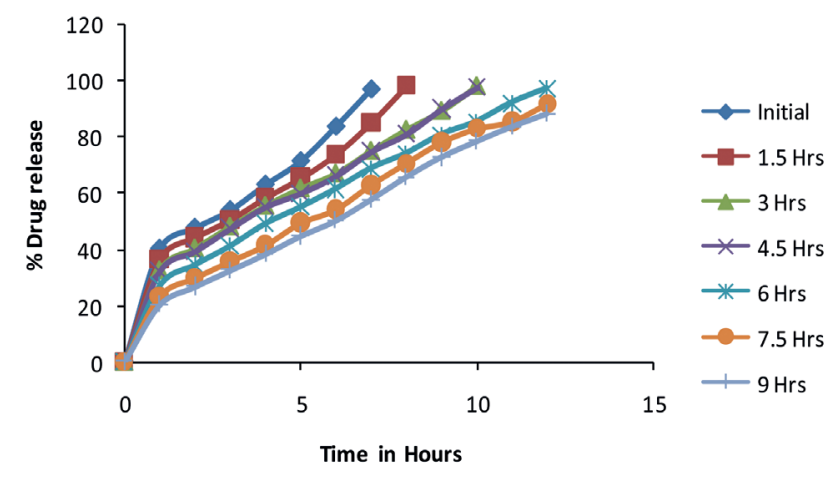

Figure 7. The dissolution profiles of formulation S3

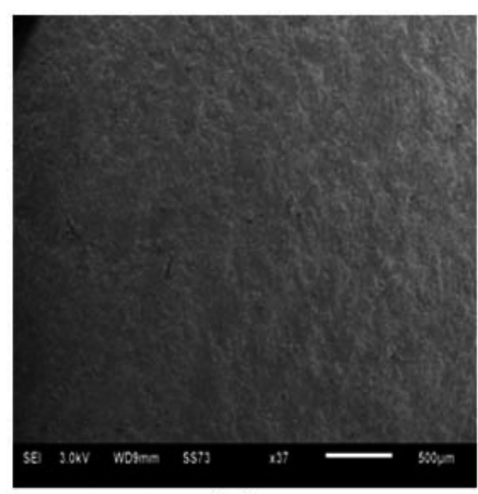

(a)

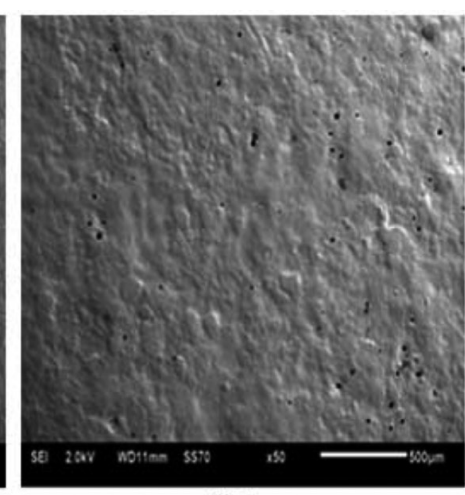

(b)

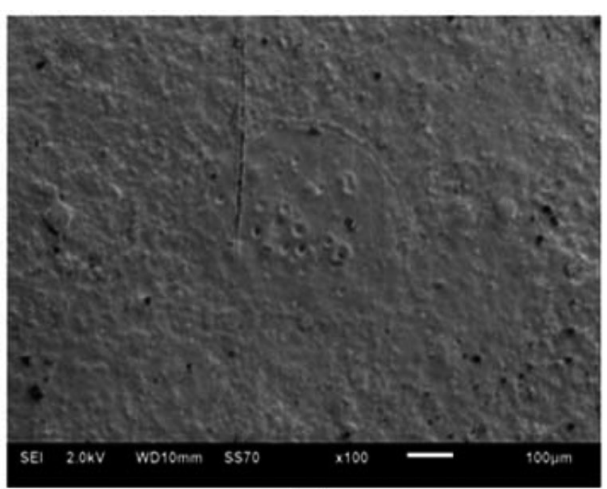

(c)

Figure 8. Surface morphology of the tablet (a) before sublimation (b) after sublimation (c) after sintering 
The optimized S2 formulation was physically evaluated for hardness and friability before and after sintering (Tables 11, 12).

\section{SEM}

Figure $8 \mathrm{a}, 8 \mathrm{~b}$ shows the morphology of S2 before and after sublimation, respectively, as viewed under SEM, ${ }^{13}$ Figure $8 \mathrm{c}$ shows the morphology of $\mathrm{S} 2$ after sintering.

The morphology of the tablet composites after sublimation is highly porous, which affects the density and floating properties of tablets. It was observed that the pore cavity on the tablets and also porosity (to some extent) was reduced after sintering. The reason attributed to the decrease in porosity was the redistribution of polymer during sintering. The polymer undergoes partial solubility in acetone vapors, which results in the redistribution of polymer molecules on the tablet surface and also into the pores formed due to sublimation.

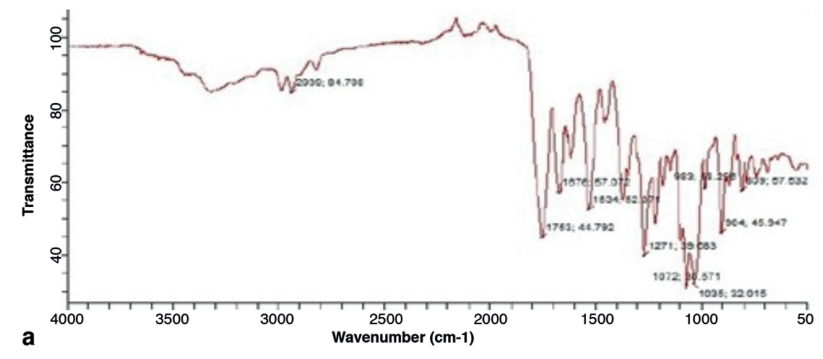

\section{FTIR studies}

The prepared tablets were subjected to FTIR studies both after sublimation and after sintering to conform the drug stability in final formulation (Figure 9).

From the results of FTIR, it was found that the functional peaks of the drug were retained after being subjected to sublimation and sintering. This implies that the drug was stable and also compatible with other excipients throughout the process.

\section{Determination of residual camphor and acetone using GC}

GC was employed to estimate the amount of residual acetone in the optimized tablets. The retention time of acetone was found as 9 mins and 30 seconds. The regression equation for the standard curve constructed by taking known concentrations $(\mu \mathrm{g} / \mathrm{mL}$ ) of acetone was found as $\mathrm{y}=1605 \mathrm{x}-177$.

The chromatogram of acetone (known concentration i.e., $10 \mu \mathrm{g} /$ $\mathrm{mL}$ ) is shown in Figure 10, non-sintered tablets (not exposed

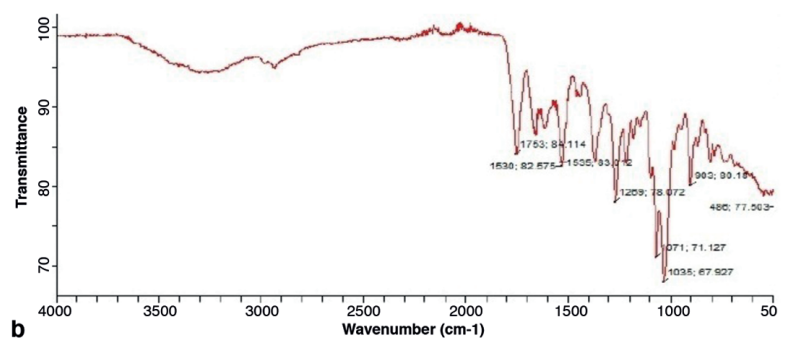

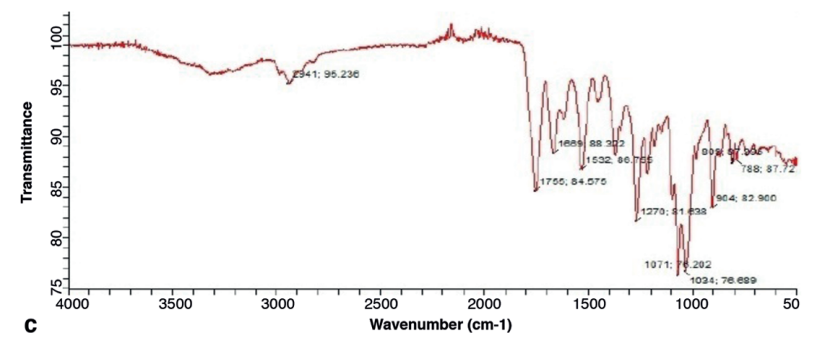

Figure 9. FTIR spectra of (a) pure cefpodoxime proxetil (b) after sublimation (c) after sintering

\section{Table 10. Model-dependent kinetic analysis for the dissolution profile of different formulation}

\begin{tabular}{llllllll}
\multirow{2}{*}{ Formulation } & Zero- order & First- order & Higuchi & \multicolumn{2}{l}{ Korsmeyer-Peppas } & Release mechanism \\
\cline { 2 - 6 } & $\mathrm{R}^{2}$ & $\mathrm{R}^{2}$ & $\mathrm{R}^{2}$ & $\mathrm{R}^{2}$ & $\mathrm{n}$ & \\
\hline F2 & 0.9842 & 0.8396 & 0.9628 & 0.9748 & 0.6348 & Anomalous transport \\
\hline F5 & 0.9691 & 0.8766 & 0.9783 & 0.9744 & 0.5549 & Anomalous transport \\
\hline
\end{tabular}

Table 11. Comparison of different physical parameters before and after sublimation

\begin{tabular}{llllllll}
\multirow{2}{*}{ Formulation } & \multirow{2}{*}{ Drug content $\mathrm{t}^{\mathrm{a}}$} & \multicolumn{5}{c}{ Before sintering } \\
\cline { 3 - 8 } & & Thickness $(\mathrm{mm})^{\mathrm{a}}$ & Density $\left(\mathrm{g} / \mathrm{cm}^{3}\right)^{\mathrm{a}}$ & Hardness $\left(\mathrm{kg} / \mathrm{cm}^{2}\right)^{\mathrm{a}}$ & Thickness $(\mathrm{mm})^{\mathrm{a}}$ & Density $\left(\mathrm{g} / \mathrm{cm}^{3}\right)^{\mathrm{a}}$ & $\mathrm{Hardness}\left(\mathrm{kg} / \mathrm{cm}^{2}\right)^{\mathrm{a}}$ \\
\hline S1 & $97.2 \pm 0.7$ & $4.6 \pm 0.01$ & $1.02 \pm 0.01$ & $5.7 \pm 0.01$ & $4.9 \pm 0.46$ & $0.85 \pm 0.01$ & $4.9 \pm 0.07$ \\
\hline S2 & $96.4 \pm 0.6$ & $4.7 \pm 0.00$ & $1.03 \pm 0.66$ & $5.7 \pm 0.00$ & $5.1 \pm 0.01$ & $0.83 \pm 0.01$ & $5.0 \pm 0.50$ \\
\hline S3 & $97.1 \pm 0.6$ & $4.8 \pm 0.24$ & $1.03 \pm 0.07$ & $5.8 \pm 0.58$ & $5.1 \pm 0.09$ & $0.84 \pm 0.05$ & $5.1 \pm 0.11$ \\
\hline
\end{tabular}

Values are expressed as mean $\pm \mathrm{SD},{ }^{\mathrm{a}}: \mathrm{n}=5$ 
to acetone vapors) in Figure 11, and the optimized tablet (tablet exposed to 6 hours of acetone) in Figure 12.

Based on results of GC, the residual concentration of acetone in the optimized tablet was found to be within the limits of generally recognized as safe (Table 13). It can be concluded that the tablets prepared by chemical sintering using acetone are safe and this method can be used as alternate technique in the preparation of matrix tablets.

\section{In vivo buoyancy study}

An in vivo buoyancy study was performed on a healthy rabbit. The animal dose was calculated using dose translation based

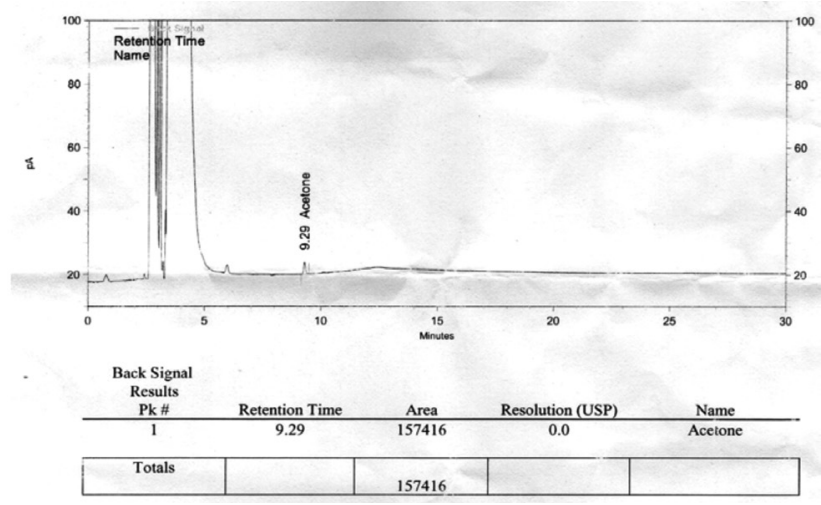

Figure 10. Chromatogram showing peak area for standard acetone concentration $(10 \mu \mathrm{g} / \mathrm{mL})$

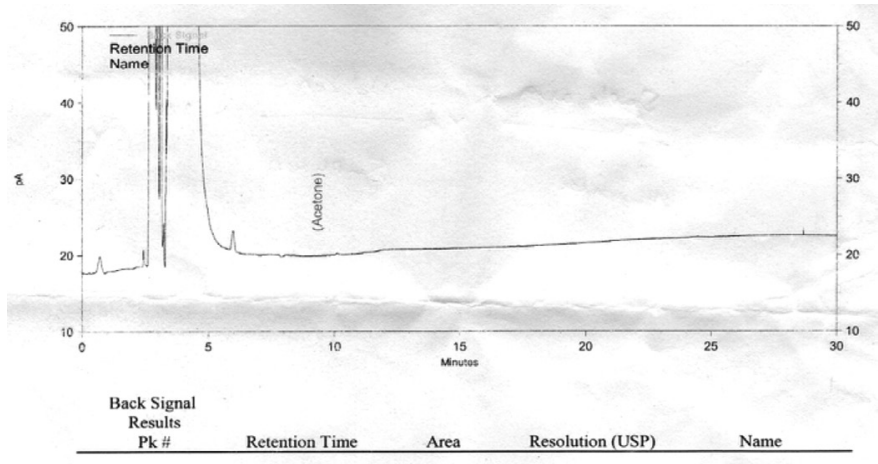

Figure 11. Chromatogram of unsintered tablets

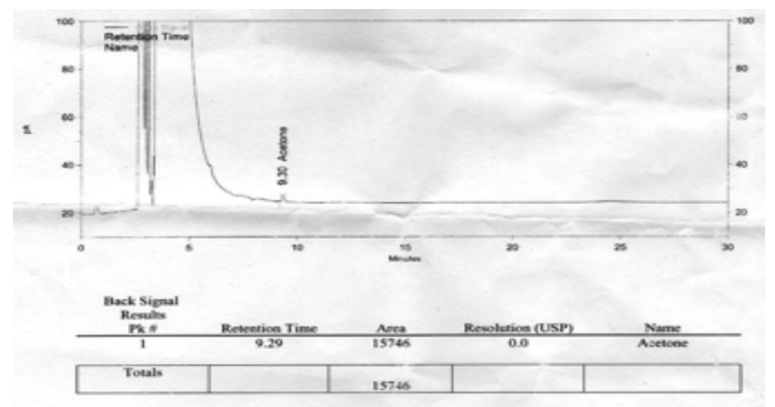

Figure 12. Chromatogram of sintered tablets i.e. 6-hour exposure to acetone vapors on BSA. Figure 13 depicts the position and nature of the tablets at different time intervals after oral administration.

From the obtained results, it was observed that the floating tablets formulated with $\mathrm{CP}$ and locust bean gum remained in the gastric region even after 8 hours of administration, indicating good retention of the tablets in the stomach region. ${ }^{17,18}$

\section{TLC}

TLC was performed to check the stability of CP when exposed to acetone vapors, by comparing the $R_{f}$ values of test with pure or standard CP.

From the TLC, no colored spot other than the principal spot of $\mathrm{CP}$ was observed in the chromatogram, which also showed a similar $\mathrm{Rf}$ value to that of the standard (0.67) (Figure 14). This indicated that CP did not degrade even after exposure to acetone vapors.

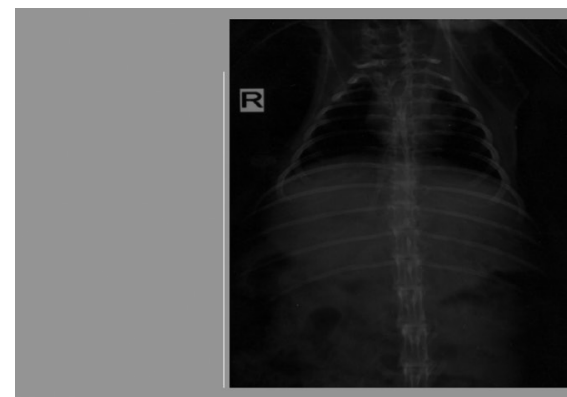

a) Before administration

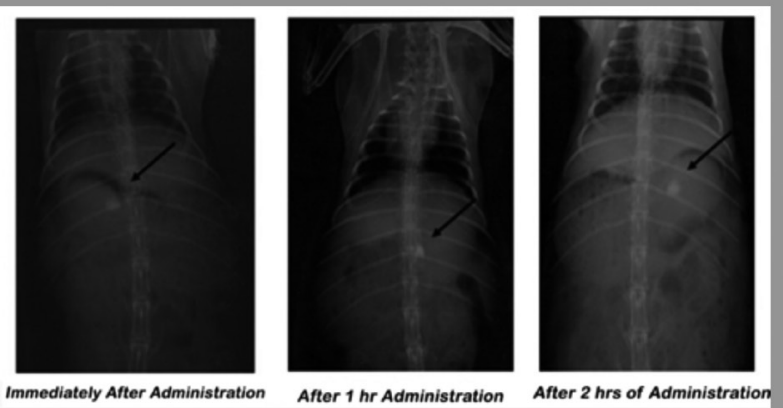

b) Immediately after administration
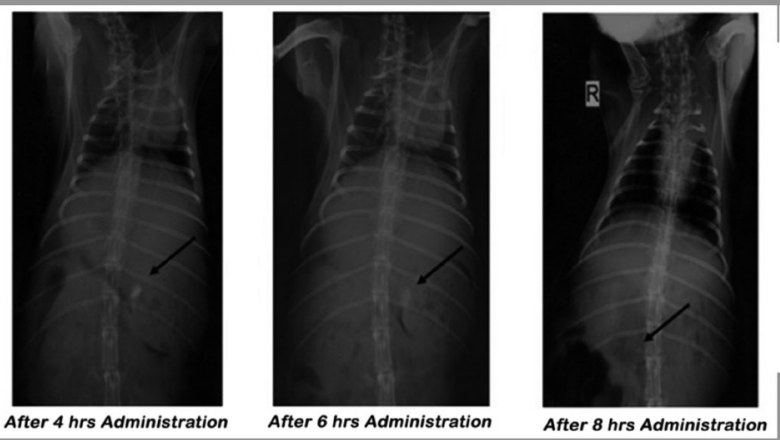

C) After 4 hrs, after 6 hrs and 8 hrs administration

Figure 13. $a, b, c) X$-rays of GIT of rabbit at different time intervals after administration of floating tablet 


\section{Anti-microbial studies}

The anti-microbial activity of the final formulation tested. Zone of inhibition studies were performed using the test drug solution and a standard (pure) antibiotic solution. Figure 15 shows the zone of inhibition of the test and standard solutions and the diameter of the zones obtained. The zone diameters are reported in Table 14.

From the microbiologic studies, similar zones of inhibition were shown for both pure drug as well as sintered matrix tablets. Therefore, it can be concluded that $\mathrm{CP}$ in the final formulation retained its antibacterial activity.

\section{Stability studies}

The optimized formulation was subjected to stability studies and the results are given in Table 15 and in Figure 16.

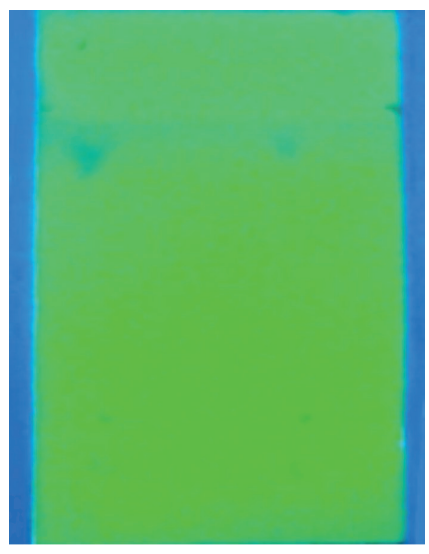

Figure 14. Chromatogram showing pure drug spot and test drug spot

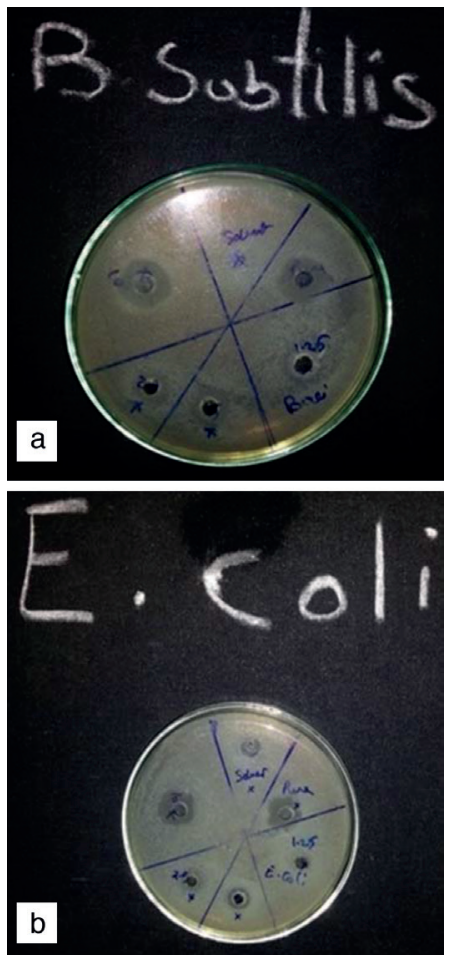

Figure 15. Composition of zone of inhibition between test and standard antibiotic solutions on (a) Bacillus subtilis (b) Escherichia coli
During the accelerated stability studies, optimized tablets were stable with insignificant changes in floating lag time, floating time, drug content, and in vitro drug release characteristics.

\section{CONCLUSIONS}

In conclusion, formulation S2, which was prepared using locust bean gum as a rate control polymer at the ratio of 0.3:1.0 (locust bean gum:drug), showed better floating properties $<14$ min and dissolution profile with $95.0 \%$ for 12 hrs compared to other formulations such as S1 and S3. Formulation S2 can be considered as the final optimized formulation for a sintered, floating gastro-retentive matrix tablet of $\mathrm{CP}$ to increase gastric residence time and thereby improve its bioavailability.

Table 12. Comparative physical evaluation of optimized formulation $\mathrm{S} 2$ both before and after sintering

\begin{tabular}{lll} 
Parameters & Before sintering & After sintering \\
\hline Hardness $\left(\mathrm{kg} / \mathrm{cm}^{2}\right)^{\mathrm{a}}$ & $5.0 \pm 0.02$ & $6.4 \pm 0.23$ \\
\hline Friability $^{\mathrm{a}}$ & $0.7 \% \pm 0.01$ & $0.5 \% \pm 0.22$ \\
\hline
\end{tabular}

Values are expressed as mean $\pm S D,{ }^{a}: n=5$

Table 13. Different concentrations of acetone with its corresponding peak area

\begin{tabular}{lll} 
Preparations & Peak area & Concentration $(\mu \mathrm{g} / \mathrm{mL})$ \\
\hline Standard acetone solution & 157416 & 10 \\
\hline Optimized formulation & 15746 & 0.9 \\
\hline
\end{tabular}

Table 14. Comparison of zones of inhibition between test and standard antibiotic solutions

\begin{tabular}{lll} 
Antibiotic solution & $\begin{array}{l}\text { Escherichia } \\
\text { coli }\end{array}$ & $\begin{array}{l}\text { Bacillus } \\
\text { subtilis }\end{array}$ \\
\hline Standard antibiotic solution $(10 \mu \mathrm{g} / 50 \mu \mathrm{L})$ & 16 & 17 \\
\hline Test antibiotic solutions $(10 \mu \mathrm{g} / 50 \mu \mathrm{L})$ & 15 & 18 \\
\hline Test antibiotic solutions $(5 \mu \mathrm{g} / 50 \mu \mathrm{L})$ & 10 & 11 \\
\hline
\end{tabular}

Note: Values of zone of inhibition in $\mathrm{mm}$, diameter of bore: $8 \mathrm{~mm}$, zone of inhibition is average of duplicate

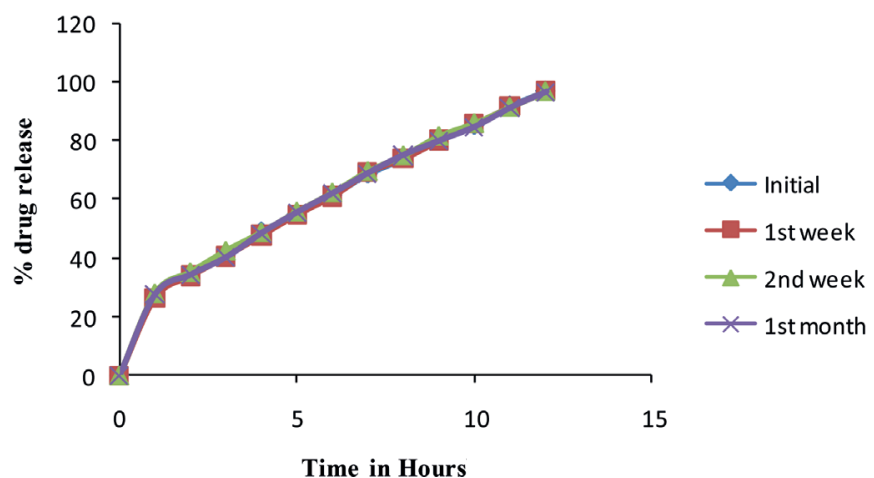

Figure 16. Percentage drug release of optimized formulation during accelerated stability studies 
Table 15. Physicochemical properties of optimized formulation during stability studies

\begin{tabular}{|c|c|c|c|c|}
\hline \multirow{2}{*}{ Parameters } & \multicolumn{4}{|l|}{ Time in weeks } \\
\hline & 0 (initial) & $1^{\text {st }}$ week & $2^{\text {nd }}$ week & $1^{\text {st }}$ month \\
\hline Floating lag time & No lag time & No lag time & No lag time & No lag time \\
\hline Floating time & $>12$ hours & $>12$ hours & $>12$ hours & $>12$ hours \\
\hline Drug content ${ }^{\mathrm{a}}(\%)$ & $98.3 \pm 0.38$ & $97.6 \pm 0.69$ & $96.5 \pm 1.06$ & $97.5 \pm 0.73$ \\
\hline Thickness $(\mathrm{mm})^{\mathrm{a}}$ & $5.1 \pm 0.01$ & $5.1 \pm 0.01$ & $5.0 \pm 0.01$ & $5.1 \pm 0.01$ \\
\hline Density $\left(\mathrm{g} / \mathrm{cm}^{3}\right)^{\mathrm{a}}$ & $0.83 \pm 0.01$ & $0.829 \pm 0.01$ & $0.83 \pm 0.01$ & $0.83 \pm 0.01$ \\
\hline Hardness $\left(\mathrm{kg} / \mathrm{cm}^{2}\right)^{\mathrm{a}}$ & $5.0 \pm 0.50$ & $5.1 \pm 0.50$ & $5.0 \pm 0.50$ & $5.0 \pm 0.50$ \\
\hline
\end{tabular}

Values are expressed as mean $\pm S D$, a: $n=5$

Conflict of Interest: No conflict of interest was declared by the authors.

\section{REFERENCES}

1. Chavanpatil M, Jain P, Chaudhari S, Shear R, Vavia P. Development of sustained release gastroretentive drug delivery system for ofloxacin: In vitro and in vivo evaluation. Int J Pharm. 2005;304:178-184.

2. Uhumwhangho MU, Ramana Murty KV. Release characteristics of diltiazem hydrochloride wax-matrix granules-Thermal sintering effect. J App Sci Environ Manage. 2011;15:365-370.

3. Sameer shafi, Chowdary KA, Nagoba S, Sachin A. Formulation and evaluation of sintered matrix tablets of diltiazem hydrochloride. Int J App Sci. 2011;3:16-19.

4. Srinivas RB, Prasanna RY, Srinivas L, Seshasayana A. Design and evaluation of Eudragit RL100 sintered matrix tablets. Indian J Pharm Sci. 2012;66:202-207.

5. Laurienzo P. Marine polysaccharides in pharmaceutical applications: An overview. Mar Drugs. 2010;8:2435-2465.

6. Rinaudo M. Main properties and current applications of some polysaccharides as biomaterials. Polym Int. 2008;57:397-430.

7. Beneke C, Viljoen AM, Hamman JH. Polymeric plant-derived excipients in drug delivery. Molecules. 2009;14:2602-2620.

8. Indian Pharmacopeia published by Indian Pharmacopeia Commission. Ghaziabad; 2010;2:751-754.

9. Siddalinga Swamy MS, Kumar Shety AS, Anil Kumar SM. UV-visible spectrophotometric methods for the estimation of cefpodoxime proxetil in bulk drug and pharmaceutical dosage form. International Journal of Pharm Tech Research. 2012;4:750-756.
10. Rao KS, Vairagkar RR, Udgirkar DB, Patil PS, Biradar KV. GastroRetentive Floating Matrix Tablets of Cefpodoxime Proxetil. J App Pharm Sci. 2011;1:190-194

11. United States Pharmacopeia 24 and National Formulary 19 by United States Pharmacopeial convention, INC. 2000;2:1941-1945.

12. Alonso-Sande M, Teijeiro-Osorio D, Remuñán-López C, Alonso MJ. Glucomannan, a promising polysaccharide for biopharmaceutical purposes. Eur J Pharm Biopharm. 2009;72:453-462.

13. Khan F, Kataram R, Ramteke S. Enhancement of bioavailability of cefpodoxime proxetil using different polymeric microparticles; AAPS PharmSciTech. 2010;11:1368-1375.

14. Ishak RA. Buoyancy-generating agents for stomach-specific drug delivery: An overview with special emphasis on floating behavior. J Pharm Pharm Sci. 2015;18:77-100.

15. Oh TO, Kim JY, Ha JM, Chi SC, Rhee YS, Park CW, Park ES. Preparation of highly porous gastroretentive metformin tablets using a sublimation method. Eur J Pharm Biopharm. 2013;83:460-467.

16. Rao BS, Seshasayana A, Himasankar K, Raju YP, Murthy KR. Design and evaluation of ethylene vinyl acetate sintered matrix tablets. Ind J Pharm Sci. 2003;65:496-502.

17. Patil SH, Talele GS. Formulation development and in vitro and in vivo evaluation of gastroretentive floating drug delivery system of Lafutidine. Asian Journal of Pharmaceutics. 2013;7:68-74.

18. Gnanaprakash K, Shekhar KBc, Chetty CMS. Floating tablets of Ranitidine $\mathrm{HCl}$ with natural polymer: An approach for gastric treatment. Int J Pharm Health Sci. 2010;1:109-115. 